\title{
Interaction between hereditary spherocytosis and the beta-thalassemia trait: A case report
}

\author{
Kalıtsal sferositoz ve beta-talasemi taşılıcıllğı arasındaki etkileşim: Olgu sunumu
}

\author{
Sunita Sharma, Sonal Jain Malhotra, Richa Chauhan \\ Department of Pathology, Lady Hardinge Medical College, Delhi University, New Delhi, India
}

To the Editor,

Coinheritance of hereditary spherocytosis (HS) and $\beta$ thalassemia is very rare. HS is a familial haemolytic disorder resulting from primary abnormality of red cell membrane. It is transmitted as an autosomal dominant trait. $\beta$ thalassemia is also a common inherited disorder. In Indians, the frequency of $\beta$ thalassemia is reported between $3.5 \& 14.9 \%$ [1]. The haemolytic anemia resulting from their coexistence has been shown to be of variable severity in different studies [2-5].

We hereby present a case of a $50 \mathrm{yr}$ old Nepalese female who came with fever, cough \& weakness without any organomegaly. $\mathrm{CBC}$ findings revealed microcytic hypochromic red cells with high red cell count $\left(>5 \times 10^{6} / \mu \mathrm{l}\right)$ and mildly increased RDW suggestive of $\beta$ TT (Table 1). Peripheral smear showed large number of microspherocytes, microcytic hypochromic cells, target cells and occasional red cells with basophilic stippling (Figure 1). Reticulocyte count was $1.5 \%$. Direct Coomb's test was negative and serum bilirubin was normal ( $1.2 \mathrm{~g} / \mathrm{dl})$. HPLC of $\mathrm{Hb}$ revealed an increased $\mathrm{Hb} \mathrm{A} 2(4.8 \%)$ and $\mathrm{Hb} F$ (6.0\%). Her son revealed very few spherocytes in peripheral smear and $\mathrm{CBC}$ findings were suggestive of $\beta$ TT. Coomb's test was negative, Hb HPLC showed high $\mathrm{HbA} 2$ (5.1\%). The incubated osmotic fragility curves of both the patient and her son were shifted to right with a tail of fragile cells. Thus, a diagnosis of HS with $\beta$ TT was made in both (Figure 2).

Inheritance of HS has been reported in association with $\alpha$ thalassemia, $\beta$ thalassemia and certain enzyme deficiencies [2-8].

The results are conflicting regarding the degree of hemolysis, when hereditary spherocytosis and

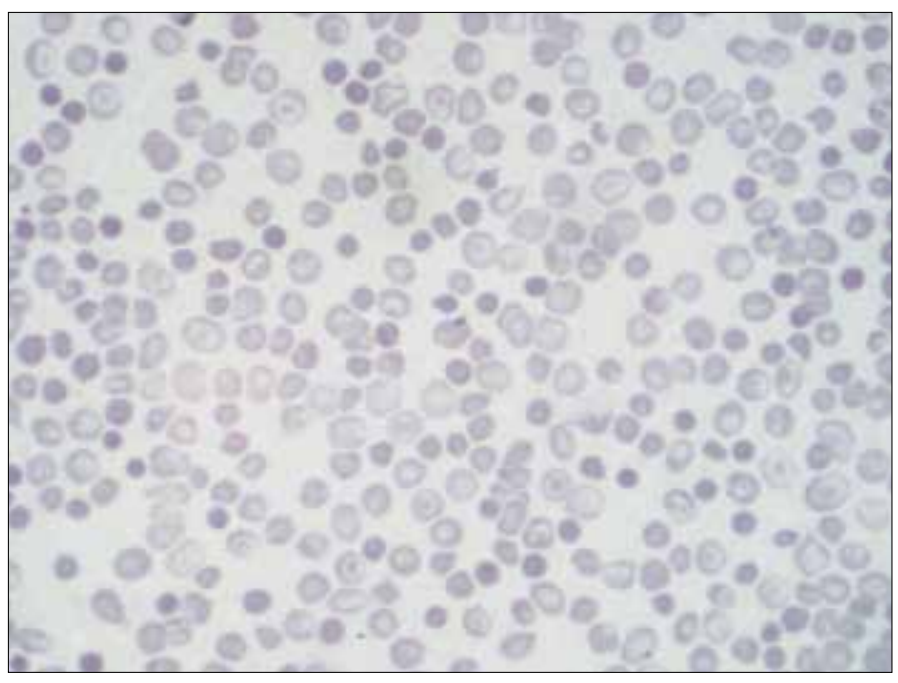

Figure 1. (400X)-Peripheral smear (Wright's stain) showing large number of microspherocytes and some target cells 
Table 1. Hematological parameters

\begin{tabular}{lccc}
\hline Parameter & Patient & Son & Husband \\
\hline Hb g/dl & 10.3 & 12.1 & 14.0 \\
\hline RBC count x 1012/l & 5.37 & 6.26 & 5.05 \\
\hline Hct \% & 34.5 & 39.9 & 43.0 \\
\hline MCV (fl) & 64.2 & 63.7 & 85.1 \\
MCH (pg) & 19.2 & 19.3 & 28.0 \\
\hline MCHC (g/dl) & 29.9 & 30.3 & 32.9 \\
RDW (\%) & 20.7 & 16.1 & 14.4 \\
TLC /cumm & 8,500 & 4,800 & 9,000 \\
\hline Plt Count x109/l & 149 & 142 & 154 \\
\hline Hb HPLC & & & \\
\hline HbA\% & 89.2 & 94 & 98.9 \\
\hline HbA2\% & 4.8 & 5.1 & 1.5 \\
\hline HbF\% & 6.0 & 0.9 & 0.4 \\
\hline
\end{tabular}

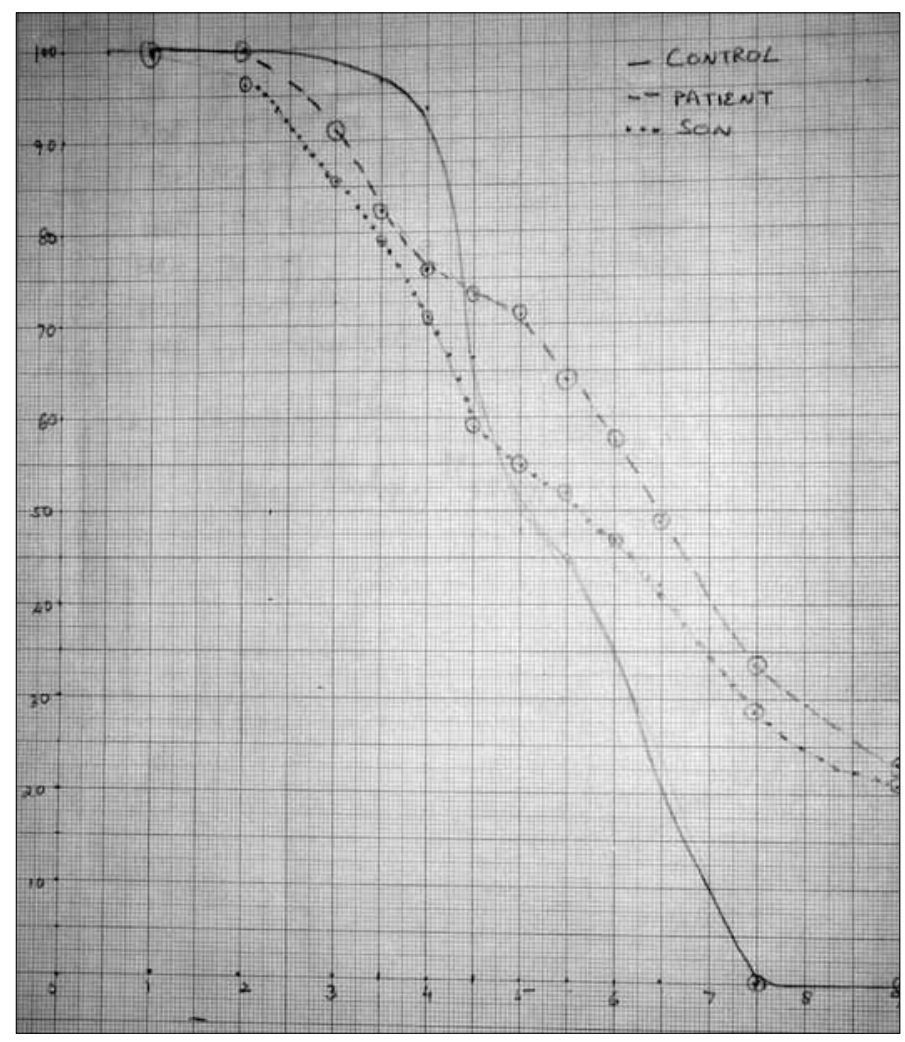

Figure 2. Incubated Osmotic fragility curve showing shift to the right compared to the control

heterozygous $\beta$ thalassemia coexist. In our case the peripheral smear showed a large number of microspherocytes, pointing towards moderate HS (20-30/ hpf). Moderate HS is associated with a chronic haemolytic anemia with modest splenomegaly and intermittent jaundice. However, our patient was asymptomatic till date. This corollary can be explained by assuming that the coinheritance of $\beta$ TT with HS probably had an influence on clinical outcome. The microcytic hypochromic red cells of $\beta$ TT and spherocytes of HS had opposite properties with regards to their fragility and this probably leads to reduced severity of hemolysis. Hence, if both HS and $\beta$ TT coexist, the later silences the HS and ameliorates the degree of hemolysis.

Written informed consent was obtained from the patient.

\section{Conflict of interest statement}

The authors of this paper have no conflicts of interest, including specific financial interests, relationships, and/or affiliations relevant to the subject matter or materials included.

\section{References}

1. Borgna-Pignatti C, Galanello. Thalassemias and related disorders: Quantitative disorders of haemoglobin synthesis. In: Wintrobe's Clinical Hematology.Lippincott Williams \& Wilkins. 2004;1320.

2. Miraglia del Giudice E, Perrotta S, Nobili B, Pinto L, Cutillo L, Iolascon A. Coexistence of hereditary spherocytosis (HS) due to band 3 deficiency and beta-thalassemia trait: partial correction of HS phenotype. Br J Haematol. 1993;85:553-7.

3. White BP, Farver M. coexixstence of hereditary spherocytosis and beta-thalassemia: case report of severe haemolytic anemia in an American black. S D J Med. 1991;44:257-61.

4. Aksoy M, Erdem S. Combination of hereditary spherocytosis and hereditary beta-thalassemia: a family study. Acta Haematol. 1968;39:183-91.

5. Andrien JM, Heusden A, Lambotte C, Hugues J. Spherocytose hereditaire et $\beta$ thalassemia: Coexistence des deux genes au sein d'une famille sicilienne. Acta Paediatrica Belgica. 1971;25:35-43.

6. Heaton DC, Fellowes AP, George PM. Concurrence of hereditary spherocytosis and alpha thalassemia. Aust N Z J Med. 1991;21:485-6.

7. Li CK, Ng MH, Cheung KL, Lam TK, Shing MM. Interaction of hereditary spherocytosis and alpha thalassemia: a family study. Acta Haematol. 1994;91:201-5.

8. McCann SR, Finkel B, Cadman S, Allan DW. Study of a kindred with hereditary spherocytosis and Glyceraldehyde-3-Phosphate Dehydrogenase Deficiency. Blood. 1976;47:171-81. 